\title{
Fashion, Luxury and Design: Store Brand Management and Global Cities' Identity
}

\author{
Elisa Arrigo ${ }^{*}$
}

\begin{abstract}
The brand enhancement policies of fashion, luxury and design firms play their part in establishing the identity of global cities. This article analyses the brand enhancement policies with the best impact on the territory (store management and events management), adopted by successful global companies (Gucci, Hermès, Kartell and Artemide) in the city of Milan, the fashion and design capital. From this analysis it emerges that, in Milan, fashion, luxury and design firms define alternative models of immaterial consumption in the city.
\end{abstract}

Keywords: Global Cities; Store Brand Management; Fashion; Luxury; Design

\section{Global Markets, Cities and Consumption}

The globalisation of the markets and the fierce competition that this triggers have driven businesses to operate outside national borders, extending their activities to the global marketplace (Brondoni 2008). This has meant both relocating manufacturing activities in countries where labour costs are lower and access to manufacturing factors is better, and establishing sales outlets in the most important foreign markets. As a matter of fact, globalisation has determined a strong interdependence between markets, revealing a high level of competition between geographical areas for investments in manufacturing, and persuading public authorities to enhance the resources available in their own areas by creating specific elements of attraction.

Inside these geographical macro-territories and in relation to the industrial activities performed there, some individual cities have acquired an important guiding role, contributing to the growth of the entire region where they are located and, at times, boosting the image of the country system they belong to. However, we must underline a significant change that has taken place in these cities. In the past, they were the place where firms located and developed their manufacturing activities, setting up factories and boosting the infrastructure necessary to guarantee the viability of transport. Today, following their relocalization strategies, these firms only maintain their headquarters in their places of origin, and the cities become centres for the exchange and transmission of ideas and knowledge. As a result, a city's

*Assistant Professor of Management, University of Milan-Bicocca (elisa.arrigo@unimib.it)

Edited by: ISTEI - University of Milan-Bicocca

ISSN: 1593-0319

Arrigo Elisa, Fashion, Luxury and Design: Store Brand Management and Global Cities Identity, Symphonya. Emerging Issues in Management (symphonya.unimib.it), n. 1, 2011, pp. 55-67

http://dx.doi.org/10.4468/2011.1.06arrigo 
differentiating power and its ability to attract investments from businesses or partnerships with public organisations and tourism, will be determined by intangible, knowledge-based resources. For example, Milan, Paris, New York and London are still considered fashion capitals even though their industrial platforms have weakened over the years. The same can be said of Stockholm and Milan, which are considered design capitals, or Helsinki, Seoul and Turin, which have recently been designated World Design Capitals.

The need therefore emerges for individual cities to fuel and encourage the exchange and transmission of ideas and knowledge between public and private businesses and entities, because their importance on the global scenario will depend on it. Obviously, in the various cities, the industrial sectors play an essential role in facilitating the creation of knowledge and intangible place-based associations. The fashion and design industries have always played a significant role in the economic growth of certain countries, and the promotion of the image of specific countries around the world. These sectors have been defined as "cultural industries" because of their territorial specificity and the effects they generate in terms of the creation of knowledge. Fashion, luxury and design are forms of knowledge that define certain cities and help to establish their attraction for external publics.

This article aims to examine how fashion, luxury and design firms can become factors of appeal and, therefore, of the development of immaterial consumption ${ }^{1}$ in specific areas of a city. In particular, we wish to investigate how the brand enhancement policies implemented by some large fashion, luxury and design firms influence the intangible component of consumption in a city. In fact, even the aspects related to the manner and place where the goods are consumed - such as the city, the district or the store where a product is purchased - seem to become significant in orienting selection processes and the behaviour of part of the public (Moye, Kincade 2003).

We have therefore based our research on the case studies (Gummesson 2000; Yin 2003) of four global firms with a high competitive profile in the fashion, luxury goods and design fields, Gucci, Hermes, Kartell and Artemide ${ }^{2}$. The city where the immaterial consumption created by these firms was analysed is Milan (with a population of approximately 1.3 million, in an area of $181 \mathrm{~km} 2$ ), which is one of the world's fashion and design capitals.

\section{Fashion, Luxury and Design Companies}

Before we start to analyse luxury and design firms, some introductory remarks are necessary. First of all, we must recognise that the fashion, luxury and design industries now cut across several commodity classes, and that the distinction between them is not always clear. In fact, in the fashion and luxury goods sector, numerous firms have adopted growth strategies based on diversification, retailing not only clothing but also accessories, perfume, creams, etc. in their points of sale. Many fashion labels have also entered the home design industry, like Armani with the Armani/Casa range of articles for the bathroom, furnishing fabrics and interior design articles, or Versace with the Versace Home range. On the other hand, some design firms have also produced fashion items. For example, Kartell has exploited the skills acquired working with plastics for furnishing accessories, recently adding its first collection of plastic ballet pumps and boots to its range. 
Secondly, over-supply (Brondoni 2010), the competitive situation in which companies offer goods in quantitative and qualitative over-abundance in relation to the public's needs, has become a structural factor of development in the market for fashion, luxury and design products. These products have a high symbolic value and communicate a way of being and a lifestyle, in which their intangible characteristics are what differentiates between them and competitors' products. In fact, fashion, luxury and design firms do not simply distribute clothing products, lamps, tables or chairs; they sell fashion and design, which are intangible factors. The most important of these are aesthetics, the brand, cultural and symbolic values and the point of sale where the product is presented and marketed.

Numerous mergers and acquisitions have taken place in the fashion and luxury industries in recent years, creating large diversified companies that control a wide range of brands ${ }^{3}$. The fashion and luxury goods sectors have been considered as fairly similar in this research, in order to contrast them with the design industry. However, there are several differences, particularly in the character of their products, the distribution policies adopted and their selling prices. To start with, luxury products have a high intrinsic and symbolic value (linked to the quality and excellence of the material and the craftsmanship), and consequently a premium price. We can also identify: inaccessible products (with an extremely high price, offering great social prestige to those who possess them); intermediate luxury goods (which address people who aspire to a higher social status with their purchases); and accessible luxury goods (addressing a vast public and with a reasonable price) (Alleres 2003). The fashion industry is traditionally broken down into: haute couture, ready-to-wear, diffusion, bridge and, finally, the mass market (Cillo, Verona 2008).

Gucci and Hermès are two very important companies in the world fashion and luxury market.

$\square$ Gucci was founded in Florence in 1921, and is now part of the Gucci Group, which is a division of PPR (Pinault, Printemps, Redouté). With 2010 sales of Euro 2,666 million, and 7,302 employees, Gucci is Gucci Group's most important brand, accounting for $66 \%$ of sales. The main product lines are: ready-to-wear, footwear, jewellery, watches and leather goods. Its distribution system is structured primarily around directly managed sales outlets located in the world's major markets. It has 317 single-brand stores in four geographical macro-areas: 115 (36\%) in Asia, 59 (19\%) in Japan, 64 (20\%) in North America and 79 (25\%) in Europe. Sales are achieved 36\% in Asia, 30\% in Europe, 12\% in Japan, $18 \%$ in America and 4\% in the Rest of the world (PPR Document Financier 2010).

$\square$ Hermès was founded in Paris in 1837 by Thierry Hermès. His descendant Jean Louis Dumas now chairs the company and still holds much of the stock capital, together with the rest of the family. It has 8,336 employees and achieved total sales of Euro 2,400.8 million in 2010. The Hermès range includes 7 product lines: women's fashion, leather goods, jewellery, perfume, menswear, leisure time and the home. The company has 317 exclusive sales outlets, 193 of which are managed directly and 124 through franchises. There are also a number of specific jewellery and watch shop-in-shops in large retail centres and 
airports. Sales points are located around the world, as follows: $40 \%$ in Europe, 15.5\% in America, 3\% in Oceania, 2\% in the Middle East and 40\% in Asia. This is reflected in the breakdown of sales: $45 \%$ (Asia), 16\% (America), 36\% (Europe) and 1\% (Rest of the world). (Hermès 2010 Annual Report).

The competitive scenario in the design world presents a large number of medium sized firms, whose brands are known all over the world but whose sales are often well below those of the large fashion and luxury companies mentioned above $\mathrm{e}^{4}$. This can be put down to two main factors. First of all, design products generally fall into the category of durable goods, with medium-high prices and a medium level of perceived risk and, as such, are the subject of infrequent purchases. Secondly, the consumption of design products is in many ways similar to the consumption of artistic assets, which demand a specific cultural training and a more articulated interest on the part of the customer than the purchase of fashion items or luxury goods, where the brand name is the greatest source of differentiation and the discriminating element.

The two firms chosen for our analysis are Kartell, which operates in the field of polycarbonate plastics, and Artemide, which focuses on top-of-the-range residential and professional lighting.

$\square$ Kartell was founded in Noviglio in 1949 by Giulio Castelli, a chemical engineer, and was taken over in 1988 by his son-in-law Claudio Luti. It has won numerous international prizes including nine Compasso d'Oro awards, and it also received a prize from the Guggenheim Museum in 2000 as the best corporate museum. In 2010, Kartell recorded sales of Euro 96 million (Amadeus Data Bank), approximately 75-80\% of which came from exports to 98 countries. It has approximately 80 employees, and is divided into two business units: Habitat Division and Labware Division; the latter focuses on research and experimentation into new materials. It currently sells its products in about 120 flagship stores and 158 shop-in-shop (i.e. areas dedicated to the company's products inside furniture stores) as well as multi-brand stores. The single-brand sales outlets break down as follows: $24 \%$ in Italy, 52\% in Europe, 7\% in Asia, 12\% in America, 2\% in Africa and 2\% in Oceania.

$\square$ The Artemide company was founded in 1960 by Ernesto Gismondi, an aeronautical engineer, and Sergio Mazza, an architect who specialised in interior design and furnishings; 2010 sales totalled Euro 123 million (Amadeus Data Bank). Artemide is renowned for its philosophy of 'The Human Light', i.e. making light into an element that can improve the quality of life, and it is one of the world's best known lighting brands. Several of its products are exhibited in the best known modern art museums, like the MOMA in New York or the Centre Georges Pompidou in Paris. Eclisse (1967), Tolomeo (1989) and Pipe (2004) are Artemide creations that have received the Compasso d'Oro award. Today the company has its headquarters in Pregnana Milanese, with 24 
subsidiaries and two Business divisions - Design and Architecture - that employ approximately 718 people. There are 54 single-brand showrooms, which break down as follows: $39 \%$ in Europe, $31 \%$ in America, 24\% in Asia and 6\% in Oceania.

\section{Brand Enhancement Policies in Fashion, Luxury and Design}

In the fashion, luxury and design industries, brand development and enhancement rely on numerous factors. First of all, the quality of the products that the brand identifies, to the point that the former may be considered a tangible dimension of the latter (Kapferer 2004). Secondly, marketing communication and advertising in particular, communicated both offline (primarily through the trade press) and online, helps to spread awareness of the brand and of its distinctive characteristics and image (Aaker 2003). Organising and participating in specific events is another way that the company can maintain relations with the public (Drengner et al. 2008). But the element that many people assimilate to a communications tool, and which represents the meeting point between product demand and corporate supply is the point of sale (Kent 2003).

In the fashion, luxury and design industries, companies often launch loyalty programmes to establish a continuous dynamic relationship with demand and to create specific purchasing opportunities. These programmes require considerable investment, to develop and support product intangible assets (product brand and product brand equity, product design and before and after-sales services) and the intangible factors of the point of sale (opening hours and days, before/after-sale support, personnel training, and location above all) (Brondoni 2010). It is these factors in particular that qualify the immaterial aspect of consumption. It is a known fact that for products with a high perceived value, the whole consumption experience i.e. the way and place where they are consumed and the atmosphere in the point of sale, are all very important (Moye, Kincade 2003).

In our analysis, we focused in particular on the management of the point of sale and of events, because both impact on induced intangible consumption in the towns where they are located. Firms that have sound brand equity can conserve it and enhance it by implementing the best store management strategies, by organising events or taking part in events in their sector of activity (Brakus et al. 2009).

Over the years, there has been an evolution in the role of the point of sales: from simply the place where demand and supply meet in a purely commercial transaction, a point of permanence which the consumer does not necessarily enter to buy a product but just to visit a place that attracts his attention. It also represents the place where the customer relates with the corporate brand. Brand management policies have therefore persuaded large fashion, luxury and design companies to locate concept stores and single-brand stores in places that already have a communicative power in relation to demand, both for their ability to generate customer traffic and for the symbolic characteristics related to them.

The retail format that best embodies the function of a sales point as a means of conveying the corporate brand identity, is the flagship store whose primary goal is to strengthen and spread awareness of the company brand in the various countries where it operates (Doyle et al. 2008). Flagship stores have specific characteristics that make them "touch points for stakeholders": they are single-brand stores; they are managed directly by the firm; they offer a wide assortment of products and a high 
standard of service to customers; they are of a considerable size (about five to eight times larger than the average for sales points in the sector) and have a strong visual impact; they are located in the world's major cities (Kozinets et al. 2002). The visual impact of these structures is the result of their large size, which simplifies the free movement of customers around the store, optimising the exploitation of the display area, and their height which makes them stand out above the others, materially revealing the importance of the corporate brand.

The investment necessary to establish a flagship store is often far superior to the returns generated by sales, but its main purpose is: "to act as publicity vehicles for the ranges and are not required to show a typical return on investment" (Fernie et al. 1998, p. 373). A significant part of the costs inherent in this retail format is determined by their chosen location in the shopping centres of the most important cities. The location of the flagship store is a strategic choice because it enhances the brand positioning, instilling the brand identity with greater luxury and prestige.

$\square$ A recent survey conducted by Cushman \& Wakefield (2011) drew up a
table of Top Locations; in first place is Fifth Avenue in New York with
annual rents of Euro 16,704 per square metre. It is followed by
Causeway Bay in Hong Kong (Euro 14,426), Ginza in Tokyo (Euro
7,750), Pitt Street Mall in Sidney (Euro 7,384), Avenue des Champs-
Elysées in Paris (Euro 7,364), New Bond Street in London (Euro 6,901)
and Via Montenapoleone in Milan (Euro 6,800).

As we can see from the Top Locations, the cities chosen as the sites of flagship stores include those historically associated with fashion, luxury and design, like Milan, Paris or New York, and emerging centres like Sidney, Shanghai or Tokyo. The concentration of several fashion or design firms in a limited space helps to fuel and spread the intangible values linked to fashion and design that are associated with these places.

$\square$ For example, in London, $85 \%$ of all the designer stores in the city are concentrated in Bond Street and Sloane Street; a similar situation can be found in New York, in Madison Avenue and Fifth Avenue where luxury firms have their stores (Moore et al. 2010).

Occupying the windows of the most prestigious shopping streets in the world's major cities is therefore a successful strategy for manufacturers of up-market products, because it enhances the company's brand image and encourages the creation of place-based intangible associations. What is more, linking a firm's brand to a city, or to a single street, helps to persuade the consumer of the product's high quality and excellence, and to raise the profile of the intangible component of consumption (Hauge et al. 2009).

Some fashion and luxury (but not design) firms share a tendency to set up a single flagship store in each foreign city or market, with some exceptional feature that differentiates it from those in other places. This policy has numerous advantages for the firm, allowing it: to curb costs, concentrating them in a single point of sale; to maintain full control of store management and, therefore, of policies to raise the brand's profile on that market; to consolidate a sense of luxury and uniqueness without diluting the essence of the brand; and, obviously, to trigger customers' 
curiosity, persuading them to visit the store. One example of this are the Gucci concept stores designed in 2008 by creative director Frida Giannini.

Architects and designers often regard flagships with interest, and considering them architectural works worthy of note (Kent 2007); they are occasionally directly involved in their planning. For example, the special flagship built by Hermès in the Ginza district of Tokyo was designed by Renzo Piano.

Where design firms are concerned on the other hand, and Kartell in particular, no flagship seems to differ from the others; this is probably due to these firms' desire to spread the brand identity through identical concept stores. For its stores, Artemide has generally tended to prefer the showroom format, but it recently inaugurated its first flagship store in Taiwan.

$\square$ In Western countries the public authorities are generally favourable to the opening of a flagship store by a fashion house, luxury goods or design firm because it triggers a virtuous circle for the sale of products in the surrounding area (Moore et al. 2010).

The flagship attracts customers into the area and the city where it is located. Moreover, since in the case of fashion, luxury or design firms we are talking about goods with a high perceived value, each store attracts a clientele with a high profile and conspicuous funds to spend. The flagship store may help to generate immaterial consumption in the physical space where it is located, and this has positive repercussions for the territory.

Where firms' involvement in events is concerned, we must underline that events come under a vast and varied category of very different activities (fairs, fashion shows, cultural or sports sponsorship, etc.). In any case, each event is programmed and of limited duration, and takes place for a specific goal. It represents a useful tool to interact with stakeholders in a context linked to the firm's field of business and potential purchasers' leisure time. What is more, it impacts on its local territory in terms of tourist flows or induced consumption in the surrounding area.

Fairs in particular allow operators in a specific field (businesses, associations, partners or institutions) to meet and forge political, commercial, manufacturing or research relationships. They are occasions at which, in addition to product sales, there is a transfer of information and an exchange of intangible knowledge about products or the evolution of the sector. "Hub events" are particularly interesting, i.e. international events organised in the countries that are undisputed leaders in the possession of expertise and production in a specific sector; for example, Italy in the clothing-fashion and furnishings-design industries.

\section{$\square$ One of the most important fairs in the design sector is the Cologne fair (IMM Cologne), but Design Weeks have also been organised recently in Beijing, Moscow and Shanghai.}

The cities that host and organise these events attempt to generate intangible design knowledge that can be linked to the cultural identity of the city itself, allowing the development of place-based intangible consumption ${ }^{5}$.

$\square$ This year, after several years' absence, Kartell was at the Cologne Fair to present its latest "Kartell Made in Milan" range of chairs, sofas 
and accessories. This offered the firm a chance to return to the German market, one of the leading European markets, with Cologne at its centre and, to this end, it also opened its own flagship store. Artemide, on the other hand, took part at the Worldwide Fair that was held in Moscow in October, and its Nord Light project produced the illumination for Bahnhofstrasse in Zurich during the Christmas season of 2010.

Where fashion and luxury are concerned, firms participate actively in numerous events such as inaugurations, trade fairs, conventions and fashion shows. The most important local fashion events are the Fashion Weeks at which collections for future seasons are presented, and where the interests of many parties converge: fashion houses, buyers and the public institutions that sponsor the event. The main international fashion shows are held in Paris, New York, London and Milan; these four cities are considered real fashion capitals (Rantisi 2004), and they set the pace for intangible knowledge about fashion (fashion knowledge hubs).

\section{Immaterial Consumption of Fashion, Luxury and Design in Milan}

We chose to analyse the city of Milan to see how the Gucci, Hermès, Kartell and Artemide firms are helping to generate specific intangible consumption, through their policies of building up and raising the profile of their brands. We will analyse the presence and location of their single-brand points of sale and their involvement in events taking place in the city.

The Gucci and Hermès stores are located in an area known as the 'Fashion Quadrilateral', bordered by Via Montenapoleone, Via Manzoni, Via della Spiga and Corso Venezia. Gucci has two stores, in Via Montenapoleone 5 and 7, and the Hermès store is in Via Sant'Andrea 21. This area has strong intangible associations with the fashion and luxury worlds. Milan's Fashion Quadrilateral is one of the world's leading districts in terms of the density and number of sales outlets of haute couture companies, jewellers, prestigious shoe stores, watchmakers and luxury accessories (Jansson, Power 2010). It is a shopping district that addresses a welldefined target of global customers: individuals who share homogeneous needs, and a high disposable income. The stores in this area do not compete with the boutiques or clothing chains in the city centre a few hundred metres away, but with the stores in the shopping districts of other large cities, that are also characterised by immaterial associations with fashion houses and luxury goods, such as Bond Street in London or Rue du Faubourg in Paris.

The streets that outline the Fashion Quadrilateral define the physical space occupied by these immaterial associations linked to fashion and luxury. Unlike other shopping districts around the world, which are imbued with intangible aspects of the fashion trade, like Fifth Avenue, New York or the Ginza district in Tokyo, in Milan's Quadrilateral it is not possible to erect new buildings, for example flagship stores over several floors. On the contrary, the number and size of sales outlets are kept small, and each one will only have one or two shop windows. On one hand, the small and limited size of the fashion Quadrilateral heightens the sense of luxury and exclusiveness while, on the other, it allows the property owners to implement 'verticalisation' policies, raising rents at their own discretion. So although the physical space is limited and fixed, its value grows constantly because of the 
intangible value and reputation that it offers to firms that locate their single-brand stores there, encouraging the creation of immaterial consumption ${ }^{6}$. In fact, the purchase of a fashion or luxury product inside the Quadrilateral acquires a peculiar value, which is linked to the purchasing experience itself, one that would probably be entirely different if it occurred in a sales point located in a suburban area. However the conservation and increase in value of the Fashion District do entail some responsibilities for society. The immaterial consumption generated in this area has triggered the creation of a network of relations that enables the companies, the Chamber of Fashion and other professional associations to lobby the public authorities with a number of requests.

Where design firms are concerned, their stores are not concentrated in a specific and limited area of Milan, but in the city centre generally.

$\square$ For example, Kartell has a flagship store in Via Turati 9, while
Artemide has two, one in Corso Monforte 19 and another in Via
Manzoni 12. Both firms have located concept stores in the city centre,
through which they aim to make their products known and to spread
their brand identity. During the recent Furniture Fair, Kartell decorated
the windows of its flagship store with a picture of Milan Cathedral,
under the logo "Made in Kartell", as a tribute to the city of Milan, the
home of contemporary design but also to strengthen the intangible
associations between design, Kartell and Milano.

It is possible to identify areas of the city where design stores in a specific commodity class are located. However, although these micro-zones can develop knowledge-based associations in the lighting or interior design sectors, they are not as extensive or circumscribed as in the case of fashion and luxury firms and the fashion district. The fact that design firms locate their sales points all over the city, often at a certain distance from each other, prevents them from creating a system to promote place-based design and it also reduces the negotiating powers of its lobbying activities with the public authorities.

Where the organisation of events in Milan is concerned, the main fashion, luxury and design events are the Fashion Weeks, the Vogue Fashion Night, the Furniture Fair with the Design Week, and the Milan Design Weekend. The Fashion Weeks (Milano Moda Donna and Milano Moda Uomo) draw together the fashion shows of the most important Italian fashion houses. They are traditionally held in the fashion houses' own showrooms, for a public made up mainly of experts (buyers, competitors, the media). The 'FuoriSalone' of the Furniture Fair (the various events that take place in Milan during the $\mathrm{Fair}^{7}$ ), has an entirely different power to involve the city. Some companies, like B\&B, have actually stopped participating in the Fair because of the high stand rental cost, preferring to concentrate on events organised in the city in the same period, in its own flagship stores.
$\square$ In 2011, Kartell launched the project 'Kartell loves Milano', inviting some symbolic celebrities from the city to rethink a cult object made by the firm, which would be sold at a charity auction. Artemide was one of the leading players at Euroluce 2011, the special two-yearly event that is recognised all over the world as the exclusive benchmark of the 
Lighting sector, when the company presented its new Design and Architectural collections in its showrooms in the city.

\section{Conclusions and Emerging Issues}

The fashion and luxury firms in Milan have developed a model of immaterial consumption that is quite unlike the model of design firms. In fact, in the city, intangible fashion and luxury based consumption is confined to a specific area and has not changed substantially over the years. The presence of the single-brand sales outlets of fashion and luxury firms, characterised by sound brand equity and very high brand awareness, means that the fashion district is constantly able to attract European and non-European purchasers during the year, as well as new firms that wish to establish stores there. This translates into an increase in the intangible value of the area, which is transformed into a permanent increase in its real estate value, as demonstrated by the rental cost per square metre of the Top Locations.

Design firms, on the other hand, continue to attribute intangible associations connected with design to Milan, but develop "episodes" of intangible consumption that are spatially separate from each other. As a result, these firms are unable to activate a virtuous circle to increase the intangible value of the areas where are their showrooms and events are organised, which the fashion world is able to achieve.

Because our research is based on case studies, the results obtained, and the comments expressed regarding the city of Milan cannot be generalised.

$\square$ For example, in New York, another fashion capital, Fifth Avenue and
Madison Avenue draw together a large number of fashion and luxury
stores, and Gucci and Hermes have also located their flagship stores
there (respectively at no. 725 Fifth Avenue and nos. 690 and 691
Madison Avenue, and at no. 15 Broad Street). Numerous design stores,
on the other hand, are located in Greene Street, where Kartell and
Artemide have their stores (at nos. 39 and 46). The same street also
hosts the shops of other design companies such as Alessi (no. 130), B\&B
(no. 138) and Moroso (no. 146). As a result, Greene Street will probably
be remembered for the intangible knowledge linked to Italian design.
The decision to concentrate Italian design stores in a circumscribed
area of a foreign city seems to be dictated by the need to strengthen the
creation of intangible consumption of Made in Italy design.

Because it represents a sum of resources, the city acquires a competitive dimension of its own, which is based not only on the territory inside its borders, where its business activities are performed, but on its capacity to develop knowledge-based intangible consumption internally. However, in addition to this, the city must be able to fuel the exchange of place-based knowledge, so as not to dispel the specific image and notoriety that it has acquired on the global arena. Increasingly frequently, new cities are now organising Design Weeks and Fashion Weeks that attract the interests of companies and public opinion, but also question the designation of the traditional European and American cities as the fashion and design capitals. 


\section{Bibliography}

Aaker A. David, The Power of the Branded Differentiator, Sloan Management Review, vol. 45, n. 1, 2003, pp. 83-87.

Alleres Danielle, Luxe-Stratégies Marketing, Economica, 2003.

Arrigo Elisa, Innovation and Market-Driven Management in Fast Fashion Companies, Symphonya. Emerging Issues in Management (symphonya.unimib.it), n. 2, 2010, pp. 67-85. http://dx.doi.org/10.4468/2010.2.06arrigo

Brakus J. Josko, Schimtt Bernd H., Zarantonello Lia, Brand Experience: What is it? How is it Measured? Does it Affect Loyalty?, Journal of Marketing, vol. 73, n. 3, 2009, pp. 52-68. http://dx.doi.org/10.1509/jmkg.73.3.52

Brondoni Silvio M., Market-Driven Management, Competitive Space and Global Network, Symphonya. Emerging Issues in Management (symphonya.unimib.it), n. 1, 2008, pp. 14-27. http://dx.doi.org/10.4468/2008.1.02brondoni

Brondoni Silvio M., Musso Fabio, Ouverture de 'Marketing Channels and Global Markets', Symphonya. Emerging Issues in Management (symphonya.unimib.it), n. 1, 2010, pp. 1-6 http://dx.doi.org/10.4468/2010.1.01ouverture

Brondoni Silvio M., Intangibles, Global Networks and Corporate Social Responsibility, Symphonya. Emerging Issues in Management (symphonya.unimib.it), n. 2, 2010, pp. 6-24. http://dx.doi.org/10.4468/2010.2.02brondoni

Cillo Paola, Verona Gianmario, Search Styles in Styles Searching: Exploring Innovation Strategies in Fashion Firms, Long Range Planning, vol. 8, n.1, 2008, pp. 1-22. http://dx.doi.org/10.1016/j.lrp.2008.08.001

Corniani Margherita, Market, Demand Segments and Demand Bubbles, Symphonya. Emerging Issues in Management (symphonya.unimib.it), n. 2, 2005, pp. 13-30.

http://dx.doi.org/10.4468/2005.2.02corniani

Cushman \& Wakefield, Main Streets Across the World, 2011.

Dobbs Richard, Smit Sven, Remes Jaana, Manyika James, Roxburgh Charle, Restrepo Alejandra, "Urban World: Mapping the Economic Power of Cities". McKynsey Global Institute, March, 2011.

Doyle Stephen A., Moore Christopher M., Doherty Anne Marie, Hamilton Morag, Brand Context and Control: the Role of the Flagship Store in B\&B Italia, International Journal of Retailing \& Distribution Management, vol. 36, n. 7, 2008, pp. 551-563. http://dx.doi.org/10.1108/09590550810880589

Drengner Jan, Gaus Hansjoerg, Jahn Steffen, Does Flow Influence the Brand Image in Event Marketing?, Journal of Advertising Research, vol. 48, n. 1, 2008, pp. 138-147.

http://dx.doi.org/10.2501/S0021849908080148

Fernie John, Moore Christopher M., Lawrie Alexander, A tale of two Cities : an Examination of Fashion Designer Retailing within London and New York, Journal of Product \& Brand Management, vol. 7, n. 5, 1998, pp. 366-378. http://dx.doi.org/10.1080/00405009808658685

Gnecchi Flavio, Brand Portofolio and Over-Supply, Symphonya. Emerging Issues in Management (symphonya.unimib.it), n. 1, 2005, pp. 56-65. http://dx.doi.org/10.4468/2005.1.05gnecchi

Gummesson Evert, Qualitative Methods in Management Research. Thousand Oaks: Sage, 2000.

Hauge Atle, Malmberg Anders, Power Dominic, The Spaces and Places of Swedish Fashion, European Planning Studies, vol. 17, n. 4, 2009, pp. 529-547.

http://dx.doi.org/10.1080/09654310802682073

Hermès Rapport Annuel, 2010.

Jansson Johan, Power Dominic, Fashioning a Global City: Global City Brand Channel in the Fashion and Design Industries, Regional Studies, vol. 44, n. 7, 2010, pp. 889-904. http://dx.doi.org/10.1080/00343400903401584

Kapferer Jean-Noel, The New Strategic Brand Management. London: Kogan, Page, 2004. 
Kent Tony, 2D23D: Management and Design Perspectives on Retail Branding, International Journal of Retail \& Distribution Management, vol. 31, n. 2/3, 2003, pp. 131-142.

http://dx.doi.org/10.1108/09590550310465503

Kent Tony, Creative Space: Design and the Retail Environment, International Journal of Retail \& Distribution Management, vol. 35, n. 9, 2007, pp. 734-745. http://dx.doi.org/10.1108/09590550710773273

Kozinets Robert V., Sherry John F., DeBerry-Spence Benet, Duhacheck Adam, Nuttavuthisi Krittinee, Storm Diana, Themed Flagship Brand Stores in the new Millenium: Theory, Practice, Prospect, Journal of Retailing, vol. 78, n. 1, 2002, pp. 17-29. http://dx.doi.org/10.1016/S0022-4359(01)00063-X

LVMH Rapport Financier, 2010.

Moore Christopher M., Doherty Anne M., Doyle Stephen A., Flagship Stores as a Market Entry Method: the Perspective of Luxury Fashion Retailing, European Journal of Marketing, vol. 44, n. $1 / 2$, 2010, pp. 139-161. http://dx.doi.org/10.1108/03090561011008646

Mosca Fabrizio, Market-Driven Management in Fashion and Luxury Industries, Symphonya. Emerging Issues in Management (symphonya.unimib.it), n. 1, 2008, pp. 65-71. http://dx.doi.org/10.4468/2008.1.06mosca

Moye Letecia N., Kincade Doris H., Shopping Orientation Segments: Exploring Differences in Store Patronage and Attitudes Toward Retail Store Environments among Female Apparel Consumers, International Journal of Consumer Studies, vol. 27, n. 1, 2003, pp. 58-71. http://dx.doi.org/10.1046/j.1470-6431.2003.00260.x

Pambiancoweek, n. 9-10, 12 may, 2011.

PPR Document Financier, 2010.

Rantisi Norma M., The Ascendance of New York Fashion, International Journal of Urban and Regional Research, vol. 28, n. 1, 2004, pp. 86-106. http://dx.doi.org/10.1111/j.0309-1317.2004.00504.x

Rosenbloom Bert, Six Classic Distribution Paradigms for Global Marketing Channel Strategy, Symphonya. Emerging Issues in Management (symphonya.unimib.it), n. 1, 2010, pp. 7-17. http://dx.doi.org/10.4468/2010.1.02rosenbloom

Weller Sally A., Fashion as Viscous Knowledge: Fashion's Role in Shaping Trans-National Garment Production, Journal of Economic Geography, vol. 7, n. 1, 2007, pp. 39-66. http://dx.doi.org/10.1093/jeg/lb1015

Yin Robert K., Case Study Research. Design and Methods, Third Edition, Thousand Oaks: Sage, 2003.

\section{Notes}

${ }^{1}$ We can use the term "immaterial consumption" to highlight the importance paid to the intangible elements of company products in consumers' assessments, because products that are competitive in terms of their physical and material attributes are almost perfectly interchangeable (Brondoni, 2010). ${ }^{2}$ In the fashion and luxury industry, we have chosen Gucci (the leading Italian company for EBITDA 2010 and in sixth place for sales among Italian fashion houses) and Hermès (the leading foreign company for the increase in 2010 sales) (Pambiancoweek, 2011). In the design industry, we have chosen Kartell and Artemide, both of which have received numerous awards, including the Compasso d'oro several times. They are both in the top 10 for 2008 sales in their respective fields (Kartell is in seventh place in the home furnishing sector, and Artemide is in fourth place in the lighting sector). Our analysis of these firms is based on direct observation, analysis of secondary sources (company documents, websites, press digests, international articles) and interviews with managers and experts in the field.

${ }^{3}$ The world's two main luxury hubs are LVMH (Louis Vuitton-Moet Hennessy) and PPR (Pinault, Printemps, Redouté). The first recorded 2010 sales (excluding spirits) of Euro 17,059 million and 
has a well-stocked brand portfolio in the following sectors: wine and alcohol, fashion, perfume and cosmetics, watches and jewellery (LVMH Document Financier 2010). PPR recorded 2010 sales (fashion and luxury goods) of Euro 14,605 million and operates in the retailing, clothing, footwear, perfume, watches and jewellery sectors (PPR Rapport Annuel 2010).

${ }^{4}$ Today, many design firms have acquired significant development dimensions and a pre-eminent position in the global competitive context, even achieving positions of excellence in some cases. Ikea is another significant case, one of the world's largest furniture retailers and a global player of "mass design", which strives constantly to cut costs, offering a vast assortment of products and very low prices.

5 A recent research project undertaken by the McKinsey Global Institute (Dobbs et al., 2011) into the role of the city in the global economy in 2007 and 2025, reveals that some of today's most important European capitals, like Milan, Frankfurt, Brussels and Madrid, will lose their positions of prestige to cities like Moscow, Beijing and Shanghai.

${ }^{6}$ The interest that many foreign companies show for the centre of Milan has encouraged the increase in commercial leases in the central streets of Milan. In 2010, the Milan Chamber of Commerce registered an increase in sales of luxury residential properties, in particular in the SpigaMontenapoleone district (OSMI Borsa Immobiliare with FIMAA Milano). What is more, data for 2010 for the Observatory of purchases by foreign tourists show that Milan is the Italian city with the greatest power to attract shopping by non-European tourists, accounting for 39\% of total tax free spending in Italy. Cf. Global Blue, (2011) Milano in testa. A Firenze boom di acquisti dei Cinesi (+90\%), Pambiancoweek (2011), 23 February.

${ }^{7}$ It was held for the first time in 1960, and celebrated its fiftieth edition this year, with 328 exhibitors in 12,000 square metres. During the Furniture Fair, parallel events are organised in 5 different areas of Milan: Fabbrica del Vapore and Triennale, Tortona, Porta Romana, Brera and Ventura Lambrate. 